Review Article

\title{
Biological Activities and Potential Oral Applications of N-Acetylcysteine: Progress and Prospects
}

\author{
Yanping Pei, ${ }^{1}$ Huan Liu, ${ }^{2}$ Yi Yang, ${ }^{3}$ Yanwei Yang, ${ }^{4}$ Yang Jiao $\mathbb{D},{ }^{5}$ Franklin R. Tay $\mathbb{D},{ }^{6}$ \\ and Jihua Chen iD ${ }^{2}$ \\ ${ }^{1}$ Stomatology Department of Navy General Hospital, Beijing 100048, China \\ ${ }^{2}$ State Key Laboratory of Military Stomatology \& National Clinical Research Center for Oral Diseases \& Shaanxi Key Laboratory of \\ Oral Diseases, Department of Prosthodontics, School of Stomatology, The Fourth Military Medical University, Xi'an 710032, China \\ ${ }^{3}$ Department of Neurosurgery, PLA Army General Hospital, Beijing 100700, China \\ ${ }^{4}$ Department of Stomatology, Lanzhou General Hospital, Lanzhou Military Area Command of Chinese PLA, Lanzhou, \\ Gansu 730050, China \\ ${ }^{5}$ Department of Stomatology, PLA Army General Hospital, Beijing 100700, China \\ ${ }^{6}$ Department of Endodontics, The Dental College of Georgia, Augusta University, Augusta, GA 30912, USA
}

Correspondence should be addressed to Yang Jiao; jiaoyang1989731@163.com, Franklin R. Tay; ftay@augusta.edu, and Jihua Chen; jhchen@fmmu.edu.cn

Received 6 December 2017; Revised 22 January 2018; Accepted 30 January 2018; Published 22 April 2018

Academic Editor: Jolanta Czuczejko

Copyright (C) 2018 Yanping Pei et al. This is an open access article distributed under the Creative Commons Attribution License, which permits unrestricted use, distribution, and reproduction in any medium, provided the original work is properly cited.

N-Acetylcysteine (NAC), a cysteine prodrug and glutathione (GSH) precursor, has been used for several decades in clinical therapeutic practices as a mucolytic agent and for the treatment of disorders associated with GSH deficiency. Other therapeutic activities of NAC include inhibition of inflammation/NF- $\kappa \mathrm{B}$ signaling and expression of proinflammatory cytokines. N-Acetylcysteine is also a nonantibiotic compound possessing antimicrobial property and exerts anticarcinogenic and antimutagenic effects against certain types of cancer. Recently, studies describing potentially important biological and pharmacological activities of NAC have stimulated interests in using NAC-based therapeutics for oral health care. The present review focused on the biological activities of NAC and its potential oral applications. The potential side effects of NAC and formulations for drug delivery were also discussed, with the intent of advancing NAC-associated treatment modalities in oral medicine.

\section{Introduction}

$\mathrm{N}$-acetylcysteine (NAC) possesses therapeutic effects over a wide range of disorders. These disorders include cystic fibrosis, acetaminophen poisoning, chronic obstructive pulmonary disease, chronic bronchitis, doxorubicin-induced cardiotoxicity, human immunodeficiency virus infection, heavy metal toxicity, and psychiatric/neurological disorders [1]. Being a $\mathrm{N}$-acetyl derivative of the amino acid L-cysteine, NAC is a cysteine prodrug and glutathione (GSH) precursor that helps scavenge free radicals and bind metal ions into complexes [1] (Figure 1). Because NAC possesses anti- inflammatory activity via inhibition of nuclear factor kappa-light-chain-enhancer of activated B cells (NF- $\kappa \mathrm{B}$ ) and modulation of proinflammatory cytokine synthesis [2], it has been used for modulating oxidative stress- and inflammation-related diseases [3]. Although NAC is not an antibiotic, it possesses antimicrobial properties and breaks down bacterial biofilms of medically relevant pathogens [4]. These characteristics render NAC a potential candidate for managing oral diseases.

The oral cavity is the first point of entry for different forms of environmental insults, including toxic chemicals, microbial infections, and mechanical injury. These insults 


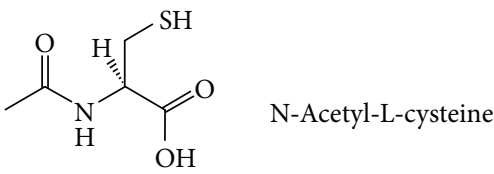<smiles>C1CCCCC1</smiles>

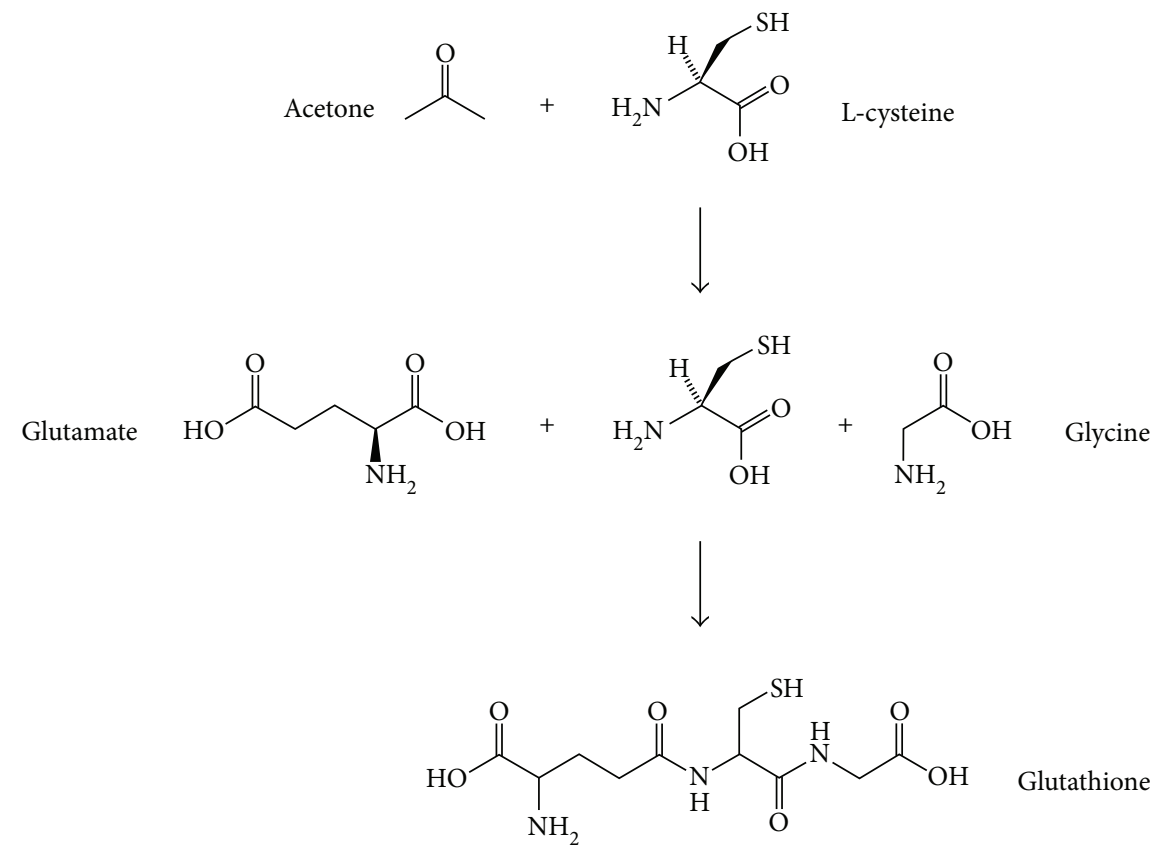

FIGURE 1: Chemical formula of $\mathrm{N}$-acetyl cysteine and its conversion to glutathione.

generate oxidative stress, induce inflammation, and may even initiate cancer (Figure 2). Some dental materials such as resins, metals, and ceramics are cytotoxic and have the potential to induce oxidative stress, DNA damage, inflammatory reactions, and cell death via apoptosis [5-7]. Disturbances in the regulation of the host inflammatory responses to bacterial infection in the dental pulp and periodontal tissues result in pulpitis and periodontitis [8]. Cigarette smoking, alcohol consumption, and betel nut chewing increase the risk of oral cancer [9]. Mechanical stresses produced during physiological masticatory activities, orthodontic tooth movement, or occlusal trauma, as well as heat stresses caused by tooth cavity preparation, light-initiated resin polymerization, or laser irradiation, may create oxidative stresses and inflammatory reactions in the dental pulp, resulting in pulpal necrosis $[10,11]$. Hence, there is a need for oral cells and tissues to efficiently detoxify xenobiotic toxicity, neutralize oxidative stress, kill invading pathogens, and eliminate inflammatory responses. In light of its potentially important biological and pharmacological activities, NAC has been advocated as a therapeutic agent in oral health care [12]. The present review focuses on the biological activities of NAC and its potential oral applications. The review also explores the potential side effects of NAC and its medical formulations. Understanding the actions of NAC and its biological effects on oral pathological processes is helpful in the design of future clinical trials and expedites clinical translation of the use of this drug in oral medicine.

\section{Antioxidation Activity}

Intracellular oxidative stress occurs when reactive oxygen species (ROS)/reactive nitrogen species (RNS) are produced beyond the cell's antioxidation capacity. Excessive oxidative stress results in oxidative modification of proteins, lipids, DNA, and subsequent cell death [13]. This process contributes to numerous pathological conditions including oral diseases [14]. Antioxidants, either natural or synthetic, are effective in diminishing the cumulative effects of oxidative stress and NAC is of particular interest. N-Acetylcysteine is a direct antioxidant that interacts with the electrophilic groups of free radicals through its free thiol side-chain. The rate constants of the reactions of NAC with various substrates under experimental conditions are summarized in Table 1. Because NAC reacts rapidly with hydroxyl radical $(\mathrm{OH})$, nitrogen dioxide $\left(\mathrm{NO}_{2}\right)$, and carbon trioxide ion $\left(\mathrm{CO}_{3}{ }^{-}\right)$, it detoxifies $\mathrm{ROS}$ produced by leukocytes [15]. Although NAC does not react directly with nitric oxide (NO), it reacts with its reduced and protonated form, nitroxyl (HNO) [16]. In addition, NAC chelates transition metal ions such as $\mathrm{Cu}^{2+}$ and $\mathrm{Fe}^{3+}$, as well as heavy metal ions such as $\mathrm{Cd}^{2+}, \mathrm{Hg}^{2+}$, and $\mathrm{Pb}^{2+}$, through 


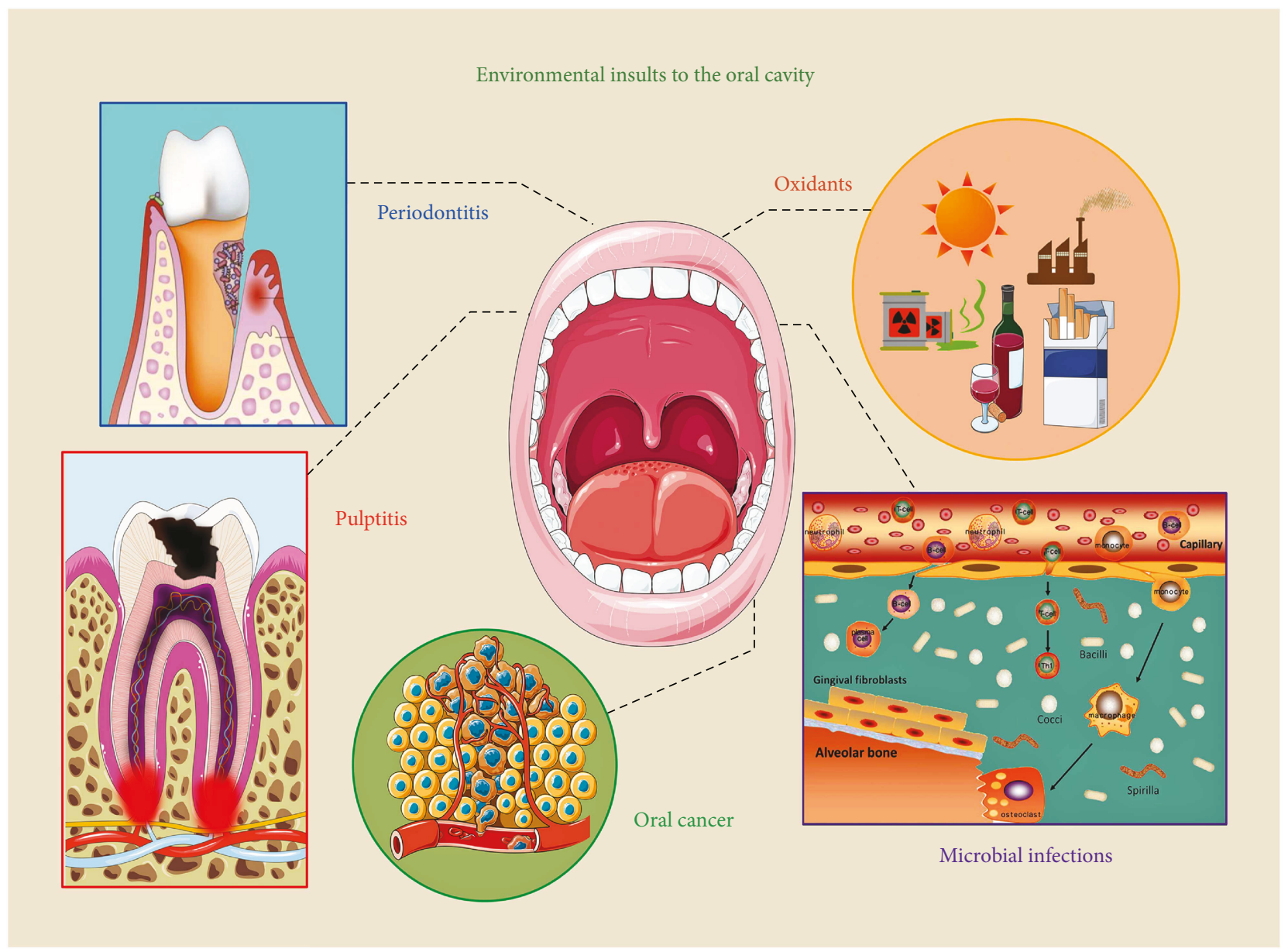

Figure 2: The oral cavity is exposed to different forms of environmental insults, including toxic chemicals, microbial infections, and mechanical injury. These insults generate oxidative stress, induce inflammation, and may even instigate cancer.

TABle 1: Rate constants of $\mathrm{N}$-acetylcysteine reactions with representative compounds (adapted from [12]).

\begin{tabular}{lccc}
\hline Compounds & $\begin{array}{c}\text { Rate constant } \\
\left(\mathrm{M}^{-1} \mathrm{~s}^{-1}\right)\end{array}$ & $\begin{array}{c}\text { Experimental } \\
\text { conditions }\end{array}$ & Reference \\
\hline $\mathrm{CO}_{3}{ }^{-}$ & $\approx 1.0 \times 10^{7}$ & $\mathrm{pH}=7 ; \mathrm{RT}$ & {$[90]$} \\
$\mathrm{HNO}$ & $1.8 \times 10^{8}$ & $\mathrm{pH}=12 ; \mathrm{RT}$ & \\
$\mathrm{HOCl}$ & $5.0 \times 10^{5}$ & $\mathrm{pH}=7.4 ; 37^{\circ} \mathrm{C}$ & {$[91]$} \\
$\mathrm{HOSCN}$ & $>10^{7}$ & $\mathrm{pH} \approx 7.4 ; 21-24^{\circ} \mathrm{C}$ & {$[92]$} \\
& $7.7 \times 10^{3}$ & $\mathrm{pH}=7.4 ; 22^{\circ} \mathrm{C}$ & {$[93]$} \\
$\mathrm{H}_{2} \mathrm{O}_{2}$ & $0.16 \pm 0.01$ & $\mathrm{pH}=7.4 ; 25^{\circ} \mathrm{C}$ & {$[94]$} \\
& $0.85 \pm 0.09$ & $\mathrm{pH}=7.4 ; 37^{\circ} \mathrm{C}$ & {$[95]$} \\
$\mathrm{NO}_{2}$ & $\approx 2.4 \times 10^{8}$ & $\mathrm{pH}>\mathrm{pK} ; \mathrm{RT}$ & {$[96]$} \\
& $\approx 1.0 \times 10^{7}$ & $\mathrm{pH}=7.4 ; \mathrm{RT}$ & {$[97]$} \\
$\mathrm{O}_{2}{ }^{-}$ & $68 \pm 6$ & $\mathrm{pH}=7 ; \mathrm{RT}$ & {$[97$} \\
$\mathrm{OH}^{-}$ & $<10^{3}$ & $\mathrm{pH}=7.4 ; 25^{\circ} \mathrm{C}$ & {$[95]$} \\
$\mathrm{ONOO}^{-}$ & $1.36 \times 10^{10}$ & $\mathrm{pH}=7 ; \mathrm{RT}$ & {$[95]$} \\
\hline
\end{tabular}

RT: room temperature.

its thiol side-chain to produce complexes. This chelation process facilitates removal of these metal ions from the body [17].
Apart from its role as a direct antioxidant, NAC also functions as an indirect antioxidant. The rate constants of the reactions of NAC with superoxide $\left(\mathrm{O}_{2}{ }^{-}\right)$, hydrogen peroxide $\left(\mathrm{H}_{2} \mathrm{O}_{2}\right)$, and peroxynitrite $\left(\mathrm{ONOO}^{-}\right)$are relatively low under physiological conditions. The indirect antioxidation action of NAC relies on replenishment of intracellular GSH, the body's major antioxidant with versatile cellular functions (see [18] for review). Considering the overwhelming antioxidation potential of GSH and the very low concentrations of NAC inside cells, it is likely that the predominant antioxidation effects of NAC are associated with maintaining GSH levels in the intracellular environment [19].

A plethora of in vitro and in vivo studies have demonstrated the protective effectiveness of NAC against various oxidative insults in the oral cavity. These insults include blue light irradiation [20], exposure to fluoride [21], $\mathrm{H}_{2} \mathrm{O}_{2}$ [22] and NO [23], and lipopolysaccharides [24], as well as dental and implantable materials [25] (Table 2). Residual monomers released from resin restorations due to incomplete polymerization could cause adverse biological reactions in oral tissues [26]. Based on in vitro studies of multiple target cells, resin monomers were detected to induce cytotoxic and genotoxic effects and specifically interfere with 


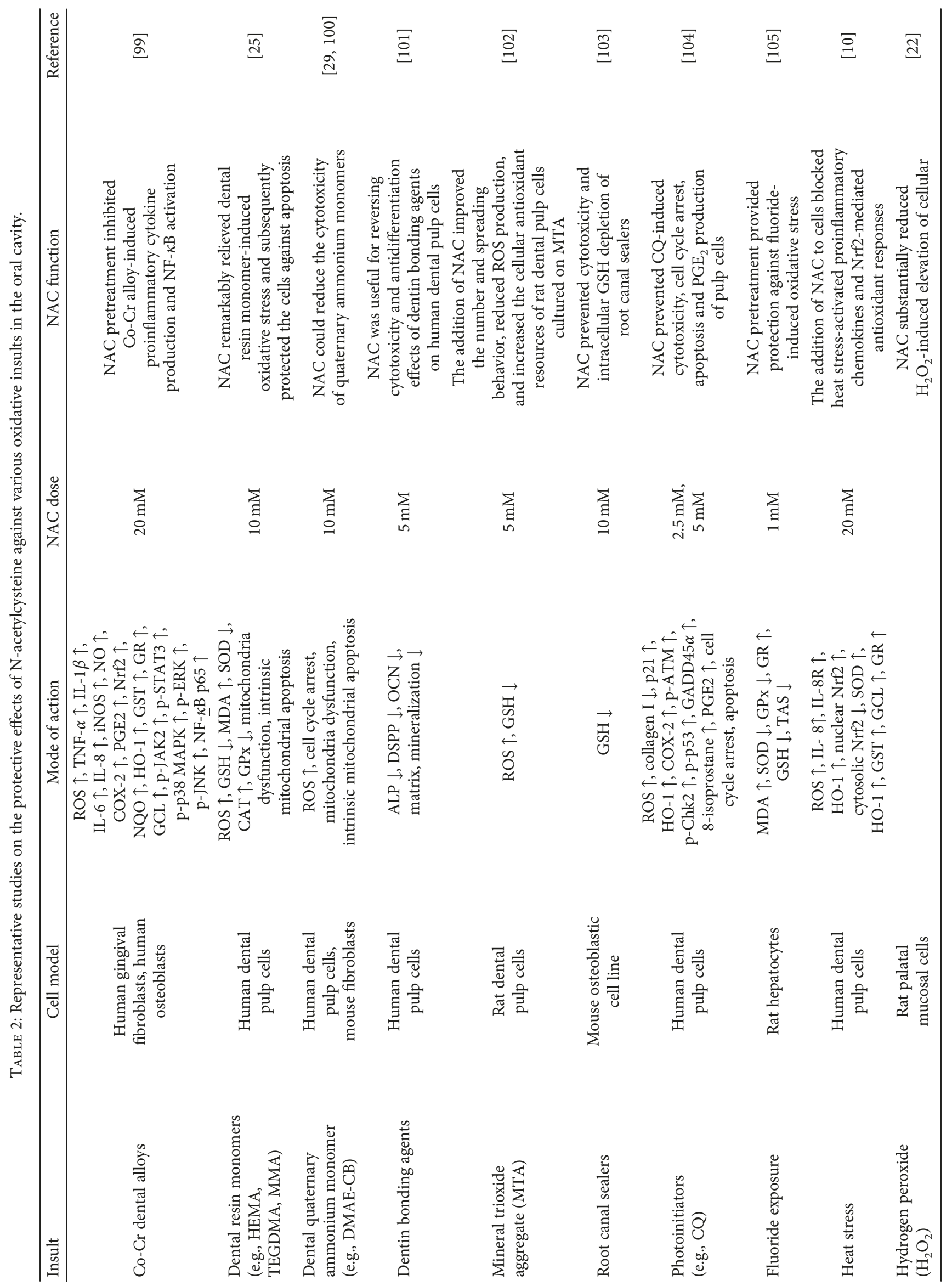




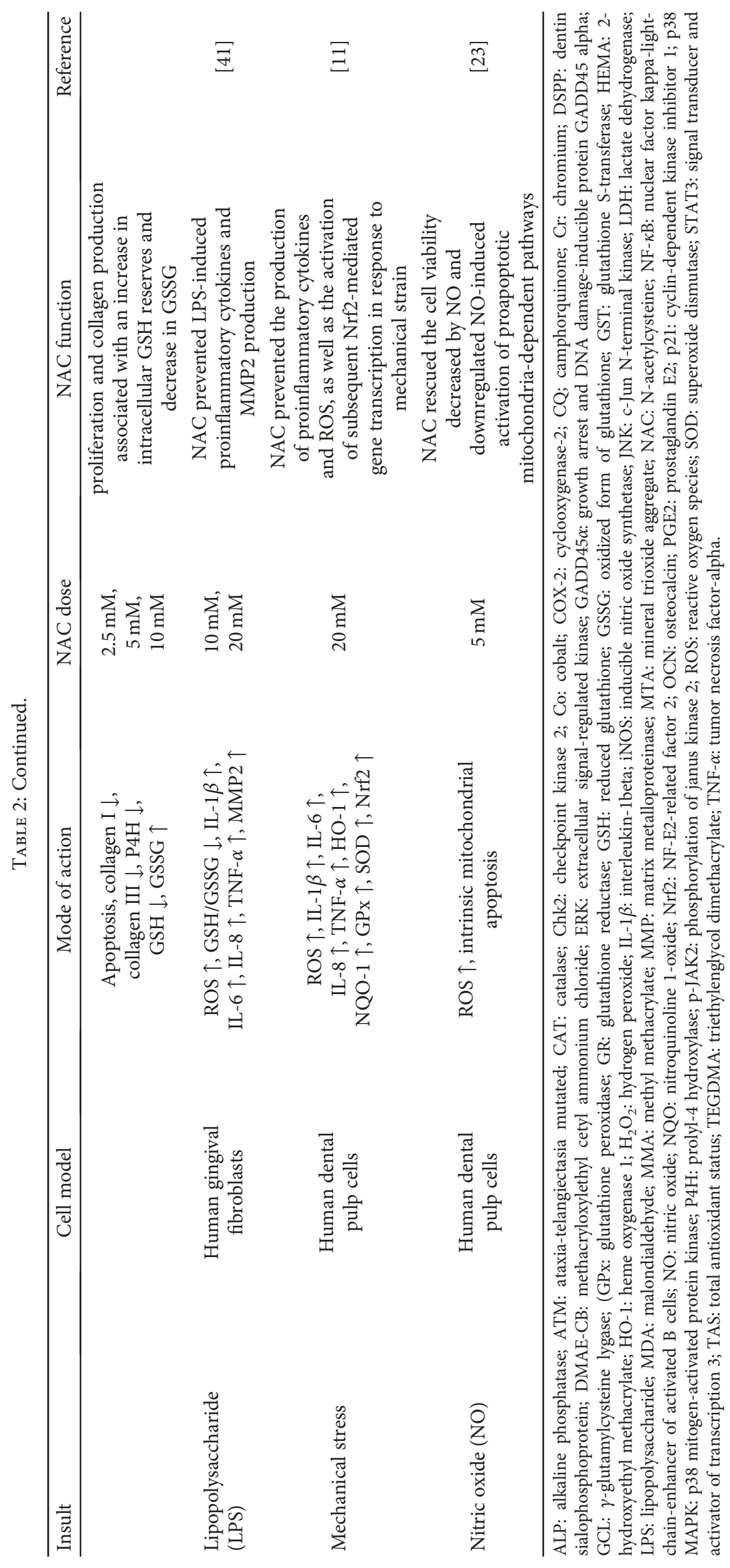



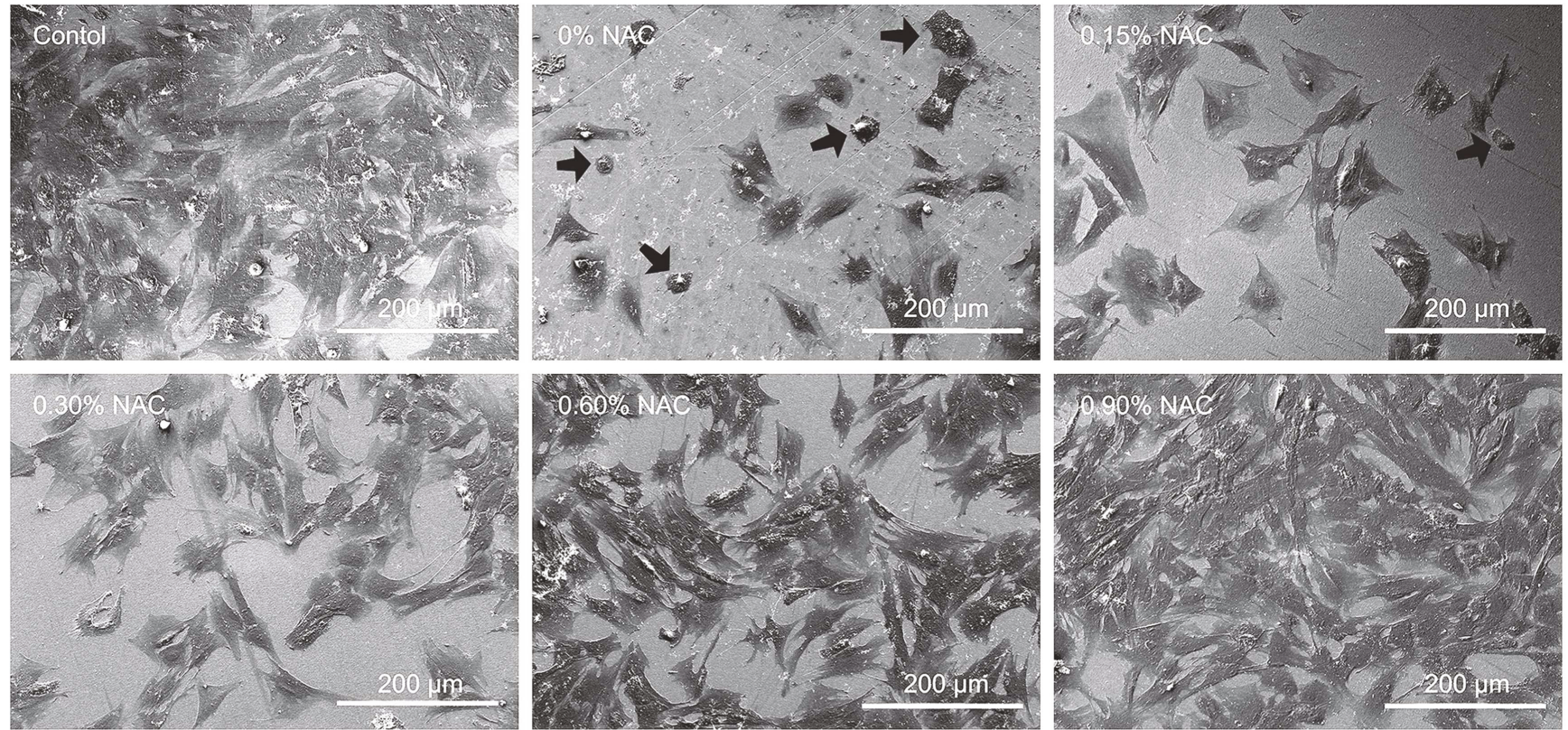

FIGURE 3: Representative scanning electron microscopy images showing attachment and morphology of human dental pulp cells on the surface of poly(methyl methacrylate) resin in the presence or absence of N-acetylcysteine (NAC). After culturing for 24 hours, human dental pulp cells grew poorly with round or collapsed appearances in subgroup $0 \mathrm{wt}$ \% NAC and subgroup $0.15 \mathrm{wt}$.\% NAC (arrows). In contrast, the cells attached and spread well with spindle or polygonal shapes in subgroups $0.3 \mathrm{wt} . \%, 0.6 \mathrm{wt} . \%$, and $0.9 \mathrm{wt} . \%$ NAC. The number of adhering cells increased as the concentration of NAC increased in the experimental poly(methyl methacrylate) resin. Similar to the control, the resin surface of subgroup $0.9 \mathrm{wt} . \% \mathrm{NAC}$ was almost fully covered by cells. Reprinted with permission [31].

various vital cellular functions [27]. Although the exact mechanism is still largely unknown, many prior reports suggest that these adverse effects are associated with monomer-induced oxidative stress as a consequence of the formation of ROS and concomitant with depletion of GSH [6]. Based on the findings that disturbance of intracellular redox balance is involved in the cytotoxic effects of resin monomers, NAC has been used and identified as an effective molecule to reduce such cytotoxicity [28]. At first, it was believed that NAC exerts protective effects against monomer-related cytotoxicity mainly through its antioxidative properties by directly scavenging overproduced ROS, meanwhile replenishing the exhausted intracellular GSH. However, very recently, some researchers have suggested a further relevant protective mechanism by providing evidence showing that NAC can directly react with the methacrylic group of resin monomers through Michaeltype addition reaction thus reducing the availability of free dental resin monomers $[29,30]$. Accordingly, NAC has been incorporated into poly(methyl methacrylate) (PMMA) dental resin. Addition of 0.15 weight percent (wt.\%) NAC remarkably improves the biocompatibility of PMMA resin without exerting significant adverse influence on its mechanical properties [31] (Figure 3). NAC has also been shown to enhance differentiation of osteoblastic cells in vitro and accelerate bone healing when added to a collagenous sponge implanted in rat femoral critical size defects $[32,33]$. These data highlight the potential of NAC for clinical application as an osteogenic enhancer in bone regeneration therapies. Significantly higher salivary ROS, lipid peroxidation, and
$\mathrm{NO}$ and nitrite levels are present in oral lichen planus patients [34], suggesting antioxidants such as NAC have therapeutic potential in managing this disease.

\section{Anti-Inflammatory Activity}

Another potential therapeutic application of NAC stems from its anti-inflammatory activity (Figure 4 ). The transcription factor NF- $\kappa$ B plays a critical role in many aspects of the inflammation cascade and immune response by regulating the expression of related genes [35]. The anti-inflammatory effect of NAC is associated with the decrease of NF- $\kappa$ B activity; NAC suppresses ubiquitination and degradation of I- $\kappa \mathrm{B}$ (an inhibitor of NF- $\kappa \mathrm{B}$ ) and thereby blocks NF- $\kappa \mathrm{B}$ nuclear translocation and activation $[36,37]$. As a direct antioxidant and GSH precursor, NAC scavenges free radicals and inhibits upstream NF- $\kappa \mathrm{B}$-activating events [38]. N-Acetylcysteine also modulates transcription activities through several pathways involving c-Fos/c-Jun, STAT, and cyclin inhibitors [39]. In oral inflammation, NAC prevents expression of lipopolysaccharide-induced proinflammatory cytokines such as interleukin-1 $\beta$ (IL-1 $\beta$ ), IL-6 and IL-8, tumor necrosis factor-alpha (TNF- $\alpha$ ), and transforming growth factor $\beta$ (TGF- $\beta$ ) in macrophages [40] and gingival fibroblasts [41]. Restorative resin materials may cause inflammatory responses by monocyte activation and changes in the levels of released cytokines. This is demonstrated by augmented proinflammatory cytokine levels in the gingival crevicular fluid [42]. N-Acetylcysteine has been used to prevent inflammation in cytotoxicity studies of resinous 


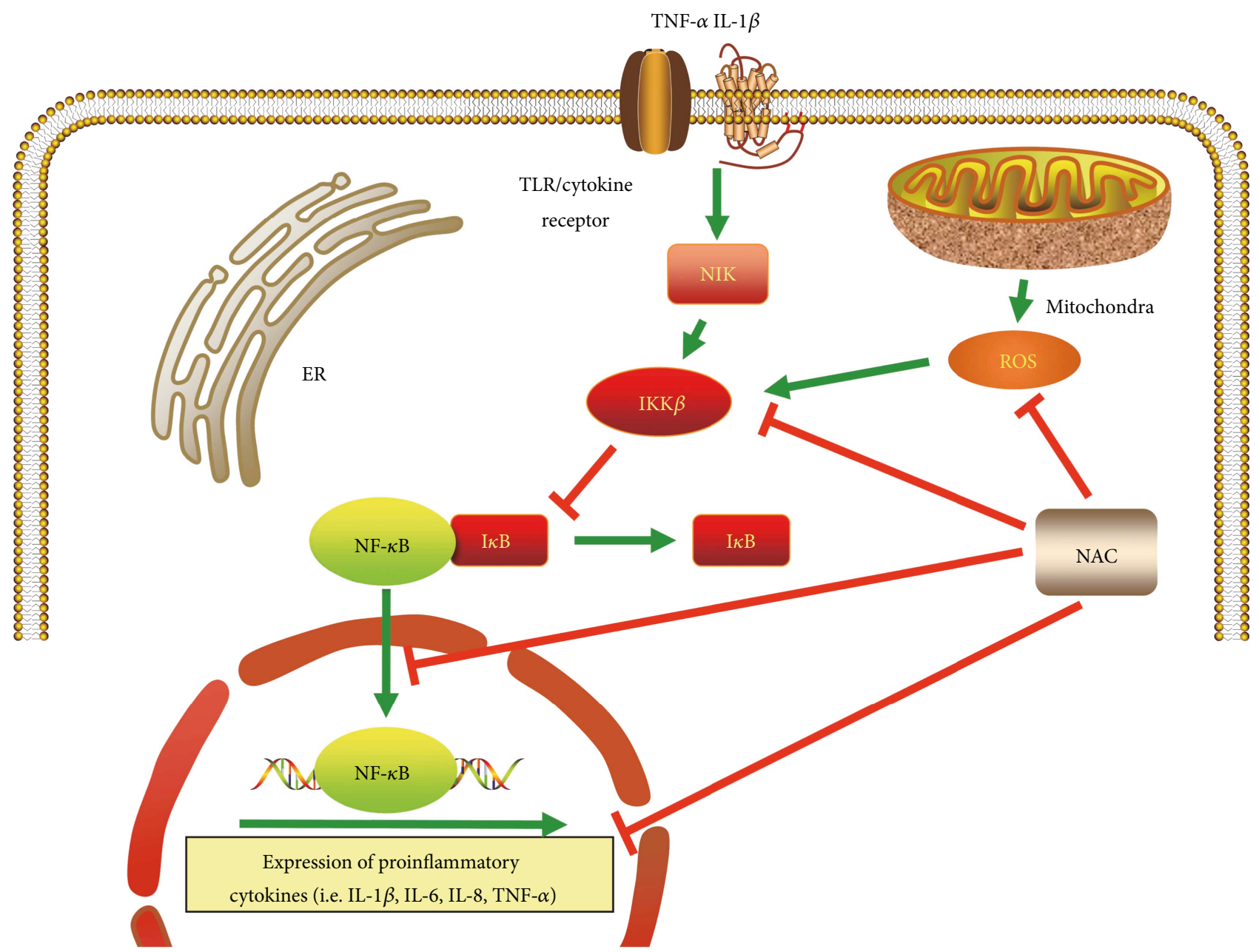

Figure 4: Model of the anti-inflammatory activity of N-acetylcysteine. NF- $\kappa \mathrm{B}$ is naturally bound to $\mathrm{I} \kappa \mathrm{B}$ that prevents its nuclear translocation. Phosphorylation of $\mathrm{I} \kappa \mathrm{B}$ by $\mathrm{IKK} \beta$ results in dissociation of $\mathrm{I} \kappa \mathrm{B}$ from NF- $\kappa \mathrm{B}$. This process facilitates nuclear translocation of NF- $\kappa \mathrm{B}$ as well as transcription of genes involved in the inflammation cascade and immune response. N-Acetylcysteine prevents activation of NF- $\kappa \mathrm{B}$ by removal of ROS, inhibition of IKK $\beta$, and nuclear translocation of NF- $\kappa$ B. N-Acetylcysteine also inhibited the synthesis of proinflammatory cytokines such as IL- $1 \beta$, IL-6, IL-8, and TNF $\alpha$. ER: endoplasmic reticulum; I $\kappa$ B: inhibitor of NF- $\kappa$ B; IKK $\beta$ : inhibitor of $\kappa \mathrm{B}$ kinase; IL: interleukin; NF- $\kappa \mathrm{B}$ : nuclear factor kappa-light-chain-enhancer of activated B cells; NIK: NF- $\kappa \mathrm{B}$-inducing kinase; ROS: reactive oxygen species; TLR: toll-like receptor; TNF- $\alpha$ : tumor necrosis factor- $\alpha$.

materials [43]. Oral administration of NAC decreases alveolar bone loss in a dose-dependent manner in a rat model of experimental periodontitis [44]. Considering that NAC acts as an osteogenesis-enhancing molecule [12], NACloaded nanotube titanium dental implants have been developed that are capable of enhancing bone regeneration and osseointegration through sustained release of NAC [45]. The loaded NAC increased the hydrophilicity of the implant surface, thereby facilitating osteoblast adhesion and proliferation. The NAC released from the loaded nanotubes also inhibits lipopolysaccharide-induced oxidative stress and inflammatory cytokines, as well as reduces expression of receptor activator of nuclear factor kappa B ligand (RANKL). These findings support the use of NAC-loaded nanotube titanium dental implants in clinical applications, although their immunomodulatory activities require further substantiation. Nevertheless, it has been reported that long-term, low-dose NAC application increases the expression of proinflammatory cytokines in lipopolysaccharide-stimulated macrophages through enhancement of kinase phosphorylation [46].

\section{Antimicrobial Activity}

Although NAC is not an antibiotic, it possesses antimicrobial properties. Since the initial demonstration of inactivation of Staphylococcus epidermidis biofilm formation by NAC in 1997 [47], many studies have demonstrated the efficacy of NAC in reducing biofilm formation induced by a broad array of medically important microorganisms (Table 3). One of those studies evaluated the antibacterial and biofilm eradication potential of NAC on Enterococcus faecalis [48], one of the most important opportunistic pathogens responsible for persistent root canal infections [49]. In that study, the authors demonstrated that NAC was effective against both the planktonic and biofilm forms of E. faecalis; antimicrobial efficacy was not reduced by the presence of dentin powder for 
TABLE 3: Representative studies on antimicrobial and antibiofilm activities of $\mathrm{N}$-acetylcysteine against various oral pathogenic microorganisms.

\begin{tabular}{|c|c|c|c|}
\hline $\begin{array}{l}\text { Pathogens } \\
\text { examined }\end{array}$ & $\begin{array}{c}\text { NAC } \\
\text { concentrations } \\
(\mathrm{mg} / \mathrm{mL})\end{array}$ & $\begin{array}{l}\text { Related } \\
\text { niche }\end{array}$ & Reference \\
\hline \multicolumn{4}{|c|}{ Gram-positive bacteria } \\
\hline $\begin{array}{l}\text { Actinomyces } \\
\text { naeslundii }\end{array}$ & $1.56-25$ & $\mathrm{C} / \mathrm{E}$ & {$[50]$} \\
\hline \multirow[t]{3}{*}{$\begin{array}{l}\text { Enterococcus } \\
\text { faecalis }\end{array}$} & $1.56-50$ & $\mathrm{E}$ & [48] \\
\hline & $1.56-25$ & $\mathrm{E}$ & {$[50]$} \\
\hline & $2.5-20$ & $\mathrm{E}$ & [57] \\
\hline $\begin{array}{l}\text { Lactobacillus } \\
\text { salivarius }\end{array}$ & $1.56-25$ & $\mathrm{C}$ & {$[50]$} \\
\hline \multirow[t]{5}{*}{$\begin{array}{l}\text { Staphylococcus } \\
\text { aureus }\end{array}$} & 20 & $\mathrm{C}$ & [106] \\
\hline & $6-24$ & $\mathrm{C}$ & {$[107]$} \\
\hline & 80 & $\mathrm{C}$ & {$[108]$} \\
\hline & $2-4$ & $\mathrm{C}$ & [109] \\
\hline & 80 & $\mathrm{C}$ & {$[110]$} \\
\hline \multirow[t]{8}{*}{$\begin{array}{l}\text { Staphylococcus } \\
\text { epidermidis }\end{array}$} & $4-40$ & C & [111] \\
\hline & $0.03-2$ & $\mathrm{C}$ & [112] \\
\hline & $4-40$ & $\mathrm{C}$ & [113] \\
\hline & 80 & $\mathrm{C}$ & [108] \\
\hline & $2-4$ & $\mathrm{C}$ & [109] \\
\hline & $0.5-32$ & $\mathrm{C}$ & [114] \\
\hline & 80 & $\mathrm{C}$ & {$[110]$} \\
\hline & $0.003-8$ & $\mathrm{C}$ & [47] \\
\hline $\begin{array}{l}\text { Streptococcus } \\
\text { mutans }\end{array}$ & $0.78-6.25$ & $\mathrm{C} / \mathrm{E}$ & {$[50]$} \\
\hline \multicolumn{4}{|c|}{ Gram-negative bacteria } \\
\hline $\begin{array}{l}\text { Acinetobacter } \\
\text { baumannii }\end{array}$ & $0.25-2$ & $\mathrm{C} / \mathrm{E}$ & {$[62]$} \\
\hline \multirow[t]{2}{*}{$\begin{array}{l}\text { Enterobacter } \\
\text { cloacae }\end{array}$} & 80 & $\mathrm{E}$ & [108] \\
\hline & $0.25-2$ & $\mathrm{E}$ & {$[62]$} \\
\hline \multirow[t]{2}{*}{$\begin{array}{l}\text { Escherichia } \\
\text { coli }\end{array}$} & $2-4$ & $\mathrm{C} / \mathrm{E} / \mathrm{P}$ & [109] \\
\hline & $0.007-8$ & $\mathrm{C} / \mathrm{E} / \mathrm{P}$ & {$[115]$} \\
\hline \multirow[t]{5}{*}{$\begin{array}{l}\text { Klebsiella } \\
\text { pneumoniae }\end{array}$} & & $\mathrm{E}$ & [106] \\
\hline & & $\mathrm{E}$ & [108] \\
\hline & & $\mathrm{E}$ & [109] \\
\hline & & $\mathrm{E}$ & {$[110]$} \\
\hline & & $\mathrm{E}$ & {$[62]$} \\
\hline $\begin{array}{l}\text { Prevotella } \\
\text { intermedia }\end{array}$ & $0.375-3$ & $\mathrm{E} / \mathrm{P}$ & [58] \\
\hline \multirow[t]{2}{*}{ Proteus spp. } & 2.5 & $\mathrm{C} / \mathrm{E} / \mathrm{P}$ & [106] \\
\hline & $2-4$ & $\mathrm{C} / \mathrm{E} / \mathrm{P}$ & [109] \\
\hline \multirow[t]{2}{*}{$\begin{array}{l}\text { Pseudomonas } \\
\text { aeruginosa }\end{array}$} & 2.5 & $\mathrm{C} / \mathrm{E} / \mathrm{P}$ & [106] \\
\hline & 12.5 & $\mathrm{C} / \mathrm{E} / \mathrm{P}$ & [116] \\
\hline
\end{tabular}

TABle 3: Continued.

\begin{tabular}{lccc}
\hline $\begin{array}{l}\text { Pathogens } \\
\text { examined }\end{array}$ & $\begin{array}{c}\text { NAC } \\
\text { concentrations } \\
(\mathrm{mg} / \mathrm{mL})\end{array}$ & $\begin{array}{c}\text { Related } \\
\text { niche }\end{array}$ & Reference \\
\hline & $3-24$ & $\mathrm{C} / \mathrm{E} / \mathrm{P}$ & {$[107]$} \\
& 80 & $\mathrm{C} / \mathrm{E} / \mathrm{P}$ & {$[108]$} \\
& $0.5-10$ & $\mathrm{C} / \mathrm{E} / \mathrm{P}$ & {$[117]$} \\
$\begin{array}{l}\text { Yeasts } \\
\text { Candida } \\
\text { albicans }\end{array}$ & $0.5-32$ & $\mathrm{C} / \mathrm{E} / \mathrm{P}$ & {$[114]$} \\
& $0.312-40$ & $\mathrm{C} / \mathrm{E} / \mathrm{P}$ & {$[118]$} \\
\hline C: caries; E: endodontic infections; P: periodontitis. &
\end{tabular}

up to 14 days. A more recent study reported that NAC has potent antibacterial effects against planktonic endodontic pathogens (Actinomyces naeslundii, Lactobacillus salivarius, Streptococcus mutans, and E. faecalis) and effectively inhibits biofilm formation by all the monospecies and multispecies bacteria [50]. Eradication of mature multispecies biofilms was also observed by scanning electron microscopy after a 10 min treatment with NAC at concentrations of $25 \mathrm{mg} / \mathrm{mL}$ or higher. The biofilm disrupting activity of NAC is significantly higher than that of saturated calcium hydroxide or $2 \%$ chlorhexidine.

During root canal treatment, it is essential to eradicate residual bacterial infections from the root canal system with intracanal medicaments such as chlorhexidine or calcium hydroxide. Although chlorhexidine exhibits substantivity, it is inactivated by dentin and has a limited ability to penetrate the deep layer of biofilms [51]. Calcium hydroxide, on the other hand, decreases the bond strength of resin-based endodontic sealer to dentin [52] and is less effective against $E$. faecalis and Candida albicans [53]. Because NAC possesses anti-inflammatory effect on lipopolysaccharide-induced inflammatory responses [40] and analgesic property for relieving postendodontic pain that is comparable to the effect of ibuprofen [54], it has immense potential to be used as an alternate intracanal medicament in root canal treatment. Some research groups have combined additional components with NAC to achieve augmented or broad-spectrum antimicrobial applications. These additional components include alexidine [55], chlorhexidine [56], taurolidine [57], and other antibiotics [58]. Despite the potent antimicrobial efficacy of NAC, when used alone or in association with antibiotics in oral cavity infections, few studies to date have evaluated the antimicrobial activity of NAC using animal models. In a murine experimental periodontitis model, a dose-dependent reduction was observed in the invasion of Fusobacterium nucleatum in immortalized human gingival epithelial cells by NAC [59]. This is achieved by inhibition of F. nucleatuminduced activation of Racl, an important regulator of actin cytoskeleton dynamics responsible for the bacterial invasion of host cells [60]. Furthermore, NAC completely eliminates experimental periodontitis induced in mice by the periodontal pathogens Prevotella gingivalis and Treponema denticola [59]. Although extensive efforts have been made in 
this field, the exact mechanisms responsible for the antimicrobial and antibiofilm activities of NAC are still speculative. These speculations include (1) inhibition of cysteine utilization in bacteria, (2) reaction between the thiol group of NAC and bacterial cell proteins, (3) reduction of bacterial extracellular polymeric substances that are responsible for bacterial adhesion and pathogenicity, and (4) disturbance of intracellular redox equilibrium with potential indirect effects on cell metabolism and intracellular signal transduction pathways [61, 62].

NAC also shows its therapeutic potential for wound healing and tissue regeneration. It was shown that NAC exerted the bacteriostatic effects on wound pathogens such as Staphylococcus aureus and Streptococcus pyogenes both in brain heart infusion (BHI) broth and on agar in vitro [63]. Addition of NAC to the collagen scaffold was shown to protect gingival fibroblasts and bone marrow-derived osteoblasts from bacterial infection by coincubation with $S$. aureus or $S$. pyogenes and preserve bacteria-induced impairment of fibroblastic viability, attachment, adhesion behavior, and osteoblastic differentiation. In addition, NAC assists the cells' ability to diminish the damaging effects of ROS and reduce inflammation during wound healing [64]. NAC was beneficial for treating grave burn injuries in a rat comb burn model when administered via the oral or intraperitoneal route [65]. The effects on wound healing of nasal mucosa were also confirmed, when NAC was intraperitoneally administered to rats with nasal trauma [66]. Experimental rat skin wounds were effectively treated with topical NAC, and the efficacy of NAC in wound healing was comparable to dexpanthenol, a molecule widely used to improve wound healing [67]. NAC has also been functionalized as a scaffold with anti-infective capabilities, thus assisting healing of soft and hard tissues. Recently, a topically administered eye drop (Lacrimera ${ }^{\circledR}$ ) based on chitosan-N-acetylcysteine (C-NAC) has been recently introduced and received CE marking in Europe. This eye drop has been shown to effectively improve corneal wound healing in a rabbit model of corneal epithelial debridement [68].

\section{Anticarcinogenic Activity}

Since the first report on the anticarcinogenic function of NAC in 1984 [69], modulation of genotoxicity, oncogenicity, and tumor progression processes by NAC has been extensively studied in cellular experiments, animal models, and human clinical trials by independent researchers. It has become apparent that NAC exerts its anticarcinogenic actions by a broad array of mechanisms including the attenuation of genotoxic ROS, modulation of metabolism and mitochondrial pathways, induction of DNA repair, inhibition of genotoxicity and cell transformation, modulation of signal transduction pathways, regulation of cell survival and apoptosis, anti-inflammatory activity, immunological effects, influence on cell cycle progression, antiangiogenetic activity, and inhibition of invasion and metastasis [70].

Oral cancer is one of the most frequently diagnosed cancers worldwide. This type of cancer constitutes $90 \%$ of head and neck cancers and involves squamous cell carcinomas of several anatomical sites such as the lip and oral cavity, pharynx, and larynx. According to the American Cancer Society, approximately 30,000 new cases of oral cancer are diagnosed in the United States alone in 2015, of which 5990 cases are fatal [71]. Despite technical advances in treatment modalities such as surgery, radiotherapy, and chemotherapy, the prognosis of oral cancer remains inauspicious; the estimated 5-year overall survival is only 56\% [72]. Major risk factors associated with the development of oral cancer include smoking, tobacco chewing, alcohol consumption, and betel nut chewing. Focusing on the potential positive effects of NAC on smoke-related carcinogenesis, a phase II trial (EUROSCAN) was conducted on 2592 patients suffering from head and neck cancer or lung cancer, most of whom were former or current smokers. No statistically significant improvement in terms of survival, event-free survival, or tumor remission was observed in those patients after a 2-year supplement of NAC (600 mg/day) [73]. By contrast, several studies reported the ability of NAC to exert protective effects against preneoplastic lesions, benign tumors, and/or malignant tumors in animal tumorigenesis models induced by individual cigarette smoke components [74]. A randomized double-blind phase II chemoprevention trial was conducted on 41 healthy smoking volunteers. After 6 months of oral NAC $(2 \times 600 \mathrm{mg} /$ day $)$, significant decrease in the investigated biomarkers was observed, including the levels of bulky DNA adducts and 8-hydroxy-2'-deoxyguanosine in bronchoalveolar lavage cells, as well as the frequency of micronuclei in mouth floor and soft palate cells [75]. The unfavorable clinical outcome of oral cancer is often associated with aberrant activation of epidermal growth factor receptor (EGFR) signaling [76]. Encouraged by the observation that NAC suppressed EGFR-induced phosphorylation in an earlier study [77], the effects of NAC in EGFR-overexpressing invasive oral cancer was conducted on cancer cell growth in a murine xenograft model [78]. The authors found that NAC suppresses growth of cancer cells by mediating the EGFR/Akt/HMG boxcontaining protein 1 signaling pathway in oral cancer cells, as well as tumor growth. N-Acetylcysteine has also been investigated as a potential agent to attenuate the side effects of platinum-based chemotherapy. By suppressing oxidative stress and oxidation-associated signals, NAC was found to reduce cisplatin-induced acute renal failure in rats [79]. A pilot randomized study with 13 head and neck cancer patients reported that transtympanic injections with NAC prior to cisplatin exposure appears to prevent cisplatininduced ototoxicity, although better delivery is required to improve the efficacy of this treatment modality [80]. The protective effect of NAC is believed to be achieved by binding directly to cisplatin molecules and acting as free radical scavengers.

\section{Potential Side Effects of NAC and Its Formulations}

Although NAC-based therapeutics has been advocated for oral health care, proactive approximations are required to 
establish safety conditions and appropriate delivery formulations. N-Acetylcysteine has a long-established safety record in adults and children; the drug has been approved by the US Food and Drug Administration since 1963. The adverse effects experienced with the use of NAC are somewhat dependent on the route of administration. The pharmacokinetics and pharmacodynamics of NAC have been investigated in a phase I clinical study of 26 volunteers with a 6-month oral administration of NAC. The major reported side effects were gastrointestinal symptoms including intestinal gas, diarrhea, nausea, and fatigue with the highest nontoxic dose being $800 \mathrm{mg} / \mathrm{m}^{2} /$ day [81]. In another clinical trial, oral administration of NAC at doses up to $8000 \mathrm{mg} /$ day was reported to cause no significant adverse reactions in patients infected with the human immunodeficiency virus [82]. In contrast, severe anaphylactoid symptoms such as flushing, pruritus, angioedema, bronchospasm, and hypotension have been reported after intravenous administration of NAC. These symptoms are likely to be attributed to the transient high plasma concentrations of NAC and are most prevalent immediately after the initial loading infusion; the symptoms subside rapidly after administration is discontinued [1]. Nevertheless, severe systemic reactions are uncommon. Considering the poor oral absorption of dietary GSH, orally administered NAC has been found to be more efficient than direct GSH administration and is as effective as intravenously administered NAC [83]. Compared with cysteine, the acetyl moiety of NAC reduces the reactivity of the thiol functionality, rendering NAC less toxic and less susceptible to oxidation to disulfide and easier for absorption and distribution [84]. N-Acetylcysteine is rapidly and almost completely absorbed after oral administration in both animals and humans; only $3 \%$ of radioactive-labeled NAC is excreted in the feces [85]. Thus, NAC is a better source of cysteine compared with parenteral administration of cysteine. Several in vitro studies demonstrated that extremely high NAC concentrations (typically $10 \mathrm{mM}$ and sometimes as high as $100 \mathrm{mM}$ ) alter protein structure and function, such as modulation of angiotensin II receptor binding [86] and TNF- $\alpha$ blocking by reducing the affinity of its receptor [87]. Collectively, the toxicity associated with NAC therapy does not appear to be a negligible issue. Oral administration is preferred despite some clinical situations where other drug delivery routes are required. A number of orally administered NAC formulations are commercially available, including Mucomyst ${ }^{\mathrm{TM}}$ (Brisol-Myers Squibb Co., Princeton, NJ, USA) as an antidote for acetaminophen overdose, PharmaNAC $^{\circledR}$ (BioAdvantex Pharma Inc., Mississauga, ON, Canada), and several formulations packaged in pill and tablet forms in Europe. Several companies also manufacture and sell NAC in combination with other daily nutritional supplements such as multivitamins and antioxidants (e.g., Swanson Health Products, Fargo, ND, USA). It is important to note that the manufacture of NAC requires prevention of NAC oxidation to the disulfide dimer $N, N^{\prime}$-diacetylcystine. Unlike NAC, the latter is pharmacologically active and causes immunologic effects at very low concentrations [88]. According to the European Good Manufacturing Practice standards, $N, N^{\prime}$-diacetylcystine should constitute less than $0.1 \%$ of commercialized NAC formulations [89].

\section{Conclusions and Prospects}

The past decade has witnessed an explosion of data regarding the multifaceted biological activities of NAC, including antioxidant, anti-inflammatory, antimicrobial, and anticarcinogenic activities. The oral cavity has continuously challenged various environmental insults that are likely to generate oxidative stress, induce inflammation, and even initiate cancer. The biological and pharmacological activities of NAC and its ability to circumvent the mechanisms of disease progression make it a potential therapeutic agent for intervention in dental and oral disorders. Still, its clinical effectiveness needs further investigations, since most of the results in this area of research are derived from in vitro and in vivo studies. The focus of future research should be the following: (i) to develop novel dental and implantable materials with improved biocompatibility by incorporating NAC, (ii) to investigate whether NAC could be used alone or with other drugs to treat oral lichen planus, (iii) to examine NAC clinically to be used as an alternate intracanal medicament in root canal treatment, (iv) to examine the clinical effectiveness of NAC for the treatment of wound healing, and (v) to evaluate the clinical application of NAC as an anticancer adjuvant for oral cancer treatment.

\section{Conflicts of Interest}

The authors declare that they have no conflicts of interest.

\section{Authors' Contributions}

Yanping Pei, Huan Liu, and Yi Yang contributed equally to this work and should be considered co-first authors.

\section{Acknowledgments}

This work was supported by Grant nos. 81600919 (principal investigator Yi Yang) and 81720108011 (principal investigator Jihua Chen) from the National Nature Science Foundation of China, Beijing Nova Program (Grant no. xx2018097) (principal investigator Yi Yang), and Program no. IRT13051 from the Program for Changjiang Scholars and Innovative Research Team in University (PCSIRT).

\section{References}

[1] K. R. Atkuri, J. J. Mantovani, L. A. Herzenberg, and L. A. Herzenberg, "N-Acetylcysteine-a safe antidote for cysteine/ glutathione deficiency," Current Opinion in Pharmacology, vol. 7, no. 4, pp. 355-359, 2007.

[2] M. Berk, G. S. Malhi, L. J. Gray, and O. M. Dean, "The promise of N-acetylcysteine in neuropsychiatry," Trends in Pharmacological Sciences, vol. 34, no. 3, pp. 167-177, 2013.

[3] G. F. Rushworth and I. L. Megson, "Existing and potential therapeutic uses for $\mathrm{N}$-acetylcysteine: the need for conversion to intracellular glutathione for antioxidant benefits," Pharmacology \& Therapeutics, vol. 141, no. 2, pp. 150-159, 2014.

[4] S. Dinicola, S. De Grazia, G. Carlomagno, and J. P. Pintucci, "N-acetylcysteine as powerful molecule to destroy bacterial biofilms: a systematic review," European Review for Medical 
and Pharmacological Sciences, vol. 18, no. 19, pp. 2942-2948, 2014.

[5] Y. Jiao, L. Niu, S. Ma, J. Li, F. R. Tay, and J. Chen, "Quaternary ammonium-based biomedical materials: state-ofthe-art, toxicological aspects and antimicrobial resistance," Progress in Polymer Science, vol. 71, pp. 53-90, 2017.

[6] S. Krifka, G. Spagnuolo, G. Schmalz, and H. Schweikl, "A review of adaptive mechanisms in cell responses towards oxidative stress caused by dental resin monomers," Biomaterials, vol. 34, no. 19, pp. 4555-4563, 2013.

[7] P. A. Mouthuy, S. J. B. Snelling, S. G. Dakin et al., "Biocompatibility of implantable materials: an oxidative stress viewpoint,” Biomaterials, vol. 109, pp. 55-68, 2016.

[8] C. L. Hahn and F. R. Liewehr, "Innate immune responses of the dental pulp to caries," Journal of Endodontics, vol. 33, no. 6, pp. 643-651, 2007.

[9] Y. C. Ko, Y. L. Huang, C. H. Lee, M. J. Chen, L. M. Lin, and C. C. Tsai, "Betel quid chewing, cigarette smoking and alcohol consumption related to oral cancer in Taiwan," Journal of Oral Pathology \& Medicine, vol. 24, no. 10, pp. 450-453, 1995.

[10] S. W. Chang, S. I. Lee, W. J. Bae et al., "Heat stress activates interleukin-8 and the antioxidant system via Nrf2 pathways in human dental pulp cells," Journal of Endodontics, vol. 35, no. 9, pp. 1222-1228, 2009.

[11] S. K. Lee, K. S. Min, Y. Kim et al., "Mechanical stress activates proinflammatory cytokines and antioxidant defense enzymes in human dental pulp cells," Journal of Endodontics, vol. 34, no. 11, pp. 1364-1369, 2008.

[12] Y. F. Feng, L. Wang, Y. Zhang et al., "Effect of reactive oxygen species overproduction on osteogenesis of porous titanium implant in the present of diabetes mellitus," Biomaterials, vol. 34, no. 9, pp. 2234-2243, 2013.

[13] B. M. Hybertson, B. Gao, S. K. Bose, and J. M. McCord, "Oxidative stress in health and disease: the therapeutic potential of Nrf2 activation," Molecular Aspects of Medicine, vol. 32, no. 4-6, pp. 234-246, 2011.

[14] A. H. Kesarwala, M. C. Krishna, and J. B. Mitchell, "Oxidative stress in oral diseases," Oral Diseases, vol. 22, no. 1, pp. 9-18, 2016.

[15] T. Akca, H. Canbaz, C. Tataroglu et al., "The effect of Nacetylcysteine on pulmonary lipid peroxidation and tissue damage," The Journal of Surgical Research, vol. 129, no. 1, pp. 38-45, 2005.

[16] N. Paolocci, M. I. Jackson, B. E. Lopez et al., "The pharmacology of nitroxyl (HNO) and its therapeutic potential: not just the janus face of NO," Pharmacology \& Therapeutics, vol. 113, no. 2, pp. 442-458, 2007.

[17] A. S. Koh, T. A. Simmons-Willis, J. B. Pritchard, S. M. Grassl, and N. Ballatori, "Identification of a mechanism by which the methylmercury antidotes $\mathrm{N}$-acetylcysteine and dimercaptopropanesulfonate enhance urinary metal excretion: transport by the renal organic anion transporter-1," Molecular Pharmacology, vol. 62, no. 4, pp. 921-926, 2002.

[18] H. Sies, "Glutathione and its role in cellular functions," Free Radical Biology \& Medicine, vol. 27, no. 9-10, pp. 916-921, 1999.

[19] K. R. Gibson, I. L. Neilson, F. Barrett et al., "Evaluation of the antioxidant properties of $\mathrm{N}$-acetylcysteine in human platelets: prerequisite for bioconversion to glutathione for antioxidant and antiplatelet activity," Journal of Cardiovascular Pharmacology, vol. 54, no. 4, pp. 319-326, 2009.
[20] A. Yoshida, Y. Shiotsu-Ogura, S. Wada-Takahashi, S. S. Takahashi, T. Toyama, and F. Yoshino, "Blue light irradiation-induced oxidative stress in vivo via ROS generation in rat gingival tissue," Journal of Photochemistry and Photobiology B, vol. 151, no. 3, pp. 48-53, 2015.

[21] M. Suzuki, C. Bandoski, and J. D. Bartlett, "Fluoride induces oxidative damage and SIRT1/autophagy through ROSmediated JNK signaling," Free Radical Biology \& Medicine, vol. 89, pp. 369-378, 2015.

[22] N. Sato, T. Ueno, K. Kubo et al., "N-Acetyl cysteine (NAC) inhibits proliferation, collagen gene transcription, and redox stress in rat palatal mucosal cells," Dental Materials, vol. 25, no. 12, pp. 1532-1540, 2009.

[23] M. Y. Park, Y. J. Jeong, G. C. Kang et al., "Nitric oxide-induced apoptosis of human dental pulp cells is mediated by the mitochondria-dependent pathway," The Korean Journal of Physiology \& Pharmacology, vol. 18, no. 1, pp. 25-32, 2014.

[24] H. Schweikl, M. Widbiller, S. Krifka et al., "Interaction between LPS and a dental resin monomer on cell viability in mouse macrophages," Dental Materials, vol. 32, no. 12, pp. 1492-1503, 2016.

[25] Y. Jiao, S. Ma, Y. Wang et al., "N-Acetyl cysteine depletes reactive oxygen species and prevents dental monomerinduced intrinsic mitochondrial apoptosis in vitro in human dental pulp cells," PLoS One, vol. 11, no. 1, article e0147858, 2016.

[26] H. Schweikl, G. Spagnuolo, and G. Schmalz, "Genetic and cellular toxicology of dental resin monomers," Journal of Dental Research, vol. 85, no. 10, pp. 870-877, 2016.

[27] Y. Jiao, S. Ma, Y. Wang, J. Li, L. Shan, and J. Chen, "Epigallocatechin-3-gallate reduces cytotoxic effects caused by dental monomers: a hypothesis," Medical Science Monitor, vol. 21, pp. 3197-3202, 2015.

[28] G. Spagnuolo, V. D’Antò, C. Cosentino, G. Schmalz, H. Schweikl, and S. Rengo, "Effect of N-acetyl-L-cysteine on ROS production and cell death caused by HEMA in human primary gingival fibroblasts," Biomaterials, vol. 27, no. 9, pp. 1803-9, 2006.

[29] Y. Jiao, S. Ma, J. Li et al., "N-Acetyl cysteine (NAC)-directed detoxification of methacryloxylethyl cetyl ammonium chloride (DMAE-CB)," PLoS One, vol. 10, no. 8, article e0135815, 2015.

[30] G. Nocca, V. D'Antò, C. Desiderio et al., "N-Acetyl cysteine directed detoxification of 2-hydroxyethyl methacrylate by adduct formation," Biomaterials, vol. 31, no. 9, pp. 25082516, 2010.

[31] Y. Jiao, S. Ma, J. Li et al., "The influences of N-acetyl cysteine (NAC) on the cytotoxicity and mechanical properties of poly-methylmethacrylate (PMMA)-based dental resin," PeerJ, vol. 3, article e868, 2015.

[32] M. Yamada, N. Tsukimura, T. Ikeda et al., "N-Acetyl cysteine as an osteogenesis-enhancing molecule for bone regeneration," Biomaterials, vol. 34, no. 26, pp. 6147-6156, 2013.

[33] J. H. Jun, S. H. Lee, H. B. Kwak et al., "N-Acetylcysteine stimulates osteoblastic differentiation of mouse calvarial cells," Journal of Cellular Biochemistry, vol. 103, no. 4, pp. 1246-1255, 2008.

[34] S. Batu, D. Ofluoglu, S. Ergun et al., "Evaluation of prolidase activity and oxidative stress in patients with oral lichen planus and oral lichenoid contact reactions," Journal of Oral Pathology \& Medicine, vol. 45, no. 4, pp. 281-288, 2016. 
[35] Y. Yamamoto and R. B. Gaynor, "Therapeutic potential of inhibition of the NF- $\kappa$ B pathway in the treatment of inflammation and cancer," The Journal of Clinical Investigation, vol. 107, no. 2, pp. 135-142, 2001.

[36] S. Oka, H. Kamata, K. Kamata, H. Yagisawa, and H. Hirata, "N-Acetylcysteine suppresses TNF-induced NF- $\kappa \mathrm{B}$ activation through inhibition of I $\kappa \mathrm{B}$ kinases," FEBS Letters, vol. 472, no. 2-3, pp. 196-202, 2000.

[37] F. Pajonk, K. Riess, A. Sommer, and W. H. McBride, "N-Acetyl-L-cysteine inhibits $26 \mathrm{~S}$ proteasome function: implications for effects on NF- $\kappa$ B activation," Free Radical Biology \& Medicine, vol. 32, no. 6, pp. 536-543, 2002.

[38] H. Kim, J. Y. Seo, K. H. Roh, J. W. Lim, and K. H. Kim, "Suppression of NF- $\kappa \mathrm{B}$ activation and cytokine production by N-acetylcysteine in pancreatic acinar cells," Free Radical Biology \& Medicine, vol. 29, no. 7, pp. 674-683, 2000.

[39] M. Zafarullah, W. Q. Li, J. Sylvester, and M. Ahmad, "Molecular mechanisms of N-acetylcysteine actions," Cellular and Molecular Life Sciences, vol. 60, no. 1, pp. 6-20, 2003.

[40] S. P. Karapinar, Y. Z. A. Ulum, B. Ozcelik et al., "The effect of $\mathrm{N}$-acetylcysteine and calcium hydroxide on TNF- $\alpha$ and TGF$\beta 1$ in lipopolysaccharide-activated macrophages," Archives of Oral Biology, vol. 68, pp. 48-54, 2016.

[41] D. Y. Kim, J. H. Jun, H. L. Lee et al., "N-Acetylcysteine prevents LPS-induced pro-inflammatory cytokines and MMP2 production in gingival fibroblasts," Archives of Pharmacal Research, vol. 30, no. 10, pp. 1283-1292, 2007.

[42] N. Celik, S. Askın, M. A. Gul, and N. Seven, "The effect of restorative materials on cytokines in gingival crevicular fluid," Archives of Oral Biology, vol. 84, pp. 139-144, 2017.

[43] C. Di Nisio, S. Zara, A. Cataldi, and V. di Giacomo, "2Hydroxyethyl methacrylate inflammatory effects in human gingival fibroblasts," International Endodontic Journal, vol. 46, no. 5, pp. 466-476, 2013.

[44] H. Toker, H. Ozdemir, K. Eren, H. Ozer, and G. Sahin, "N-Acetylcysteine, a thiol antioxidant, decreases alveolar bone loss in experimental periodontitis in rats," Journal of Periodontology, vol. 80, no. 4, pp. 672-678, 2009.

[45] Y. H. Lee, G. Bhattarai, I. S. Park et al., "Bone regeneration around N-acetyl cysteine-loaded nanotube titanium dental implant in rat mandible," Biomaterials, vol. 34, no. 38, pp. 10199-10208, 2013.

[46] T. Ohnishi, K. Bandow, K. Kakimoto, J. Kusuyama, and T. Matsuguchi, "Long-time treatment by low-dose N-acetylL-cysteine enhances proinflammatory cytokine expressions in LPS-stimulated macrophages," PLoS One, vol. 9, no. 2, article e87229, 2014.

[47] C. Pérez-Giraldo, A. Rodríguez-Benito, F. J. Morán, C. Hurtado, M. T. Blanco, and A. C. Gómez-García, "Influence of $\mathrm{N}$-acetylcysteine on the formation of biofilm by Staphylococcus epidermidis," The Journal of Antimicrobial Chemotherapy, vol. 39, no. 5, pp. 643-646, 1997.

[48] S. Y. Quah, S. Wu, J. N. Lui, C. P. Sum, and K. S. Tan, "N-Acetylcysteine inhibits growth and eradicates biofilm of Enterococcus faecalis," Journal of Endodontics, vol. 38, no. 1, pp. 81-85, 2012.

[49] C. Stuart, S. Schwartz, T. Beeson, and C. Owatz, "Enterococcus faecalis: its role in root canal treatment failure and current concepts in retreatment," Journal of Endodontics, vol. 32, no. 2, pp. 93-98, 2006.
[50] J. H. Moon, Y. S. Choi, H. W. Lee, J. S. Heo, S. W. Chang, and J. Y. Lee, "Antibacterial effects of N-acetylcysteine against endodontic pathogens," Journal of Microbiology, vol. 54, no. 4, pp. 322-329, 2016.

[51] I. Portenier, H. Haapasalo, D. Orstavik, M. Yamauchi, and M. Haapasalo, "Inactivation of the antibacterial activity of iodine potassium iodide and chlorhexidine digluconate against Enterococcus faecalis by dentin, dentin matrix, typeI collagen, and heat-killed microbial whole cells," Journal of Endodontics, vol. 28, no. 9, pp. 634-637, 2002.

[52] J. V. B. Barbizam, M. Trope, É. C. N. Teixeira, M. TanomaruFilho, and F. B. Teixeira, "Effect of calcium hydroxide intracanal dressing on the bond strength of a resin-based endodontic sealer," Brazilian Dental Journal, vol. 19, no. 3, pp. 224-227, 2008.

[53] Z. Mohammadi and P. M. H. Dummer, "Properties and applications of calcium hydroxide in endodontics and dental traumatology," International Endodontic Journal, vol. 44, no. 8, pp. 697-730, 2011.

[54] M. Ehsani, A.-A. Moghadamnia, S. Zahedpasha et al., "The role of prophylactic ibuprofen and $\mathrm{N}$-acetylcysteine on the level of cytokines in periapical exudates and the posttreatment pain," Daru, vol. 20, no. 1, p. 30, 2012.

[55] L. F. M. Silveira, P. Baca, M. T. Arias-Moliz, A. RodríguezArchilla, and C. M. Ferrer-Luque, "Antimicrobial activity of alexidine alone and associated with $\mathrm{N}$-acetylcysteine against Enterococcus faecalis biofilm," International Journal of Oral Science, vol. 5, no. 3, pp. 146-149, 2013.

[56] U. Palaniswamy, S. R. Lakkam, S. Arya, and S. Aravelli, "Effectiveness of $\mathrm{N}$-acetyl cysteine, 2\% chlorhexidine, and their combination as intracanal medicaments on Enterococcus faecalis biofilm," Journal of Conservative Dentistry, vol. 19, no. 1, pp. 17-20, 2016.

[57] A. T. Ulusoy, E. Kalyoncuoglu, A. Reis, and Z. C. Cehreli, "Antibacterial effect of $\mathrm{N}$-acetylcysteine and taurolidine on planktonic and biofilm forms of Enterococcus faecalis," Dental Traumatology, vol. 32, no. 3, pp. 212-218, 2016.

[58] J. H. Moon, E. Y. Jang, K. S. Shim, and J. Y. Lee, "In vitro effects of $\mathrm{N}$-acetyl cysteine alone and in combination with antibiotics on Prevotella intermedia," Journal of Microbiology, vol. 53, no. 5, pp. 321-329, 2015.

[59] J. Alam, K. J. Baek, Y. S. Choi, Y. C. Kim, and Y. Choi, "N-acetylcysteine and the human serum components that inhibit bacterial invasion of gingival epithelial cells prevent experimental periodontitis in mice," Journal of Periodontal \& Implant Science, vol. 44, no. 6, pp. 266-273, 2014.

[60] L. Van Aelst and C. D'Souza-Schorey, "Rho GTPases and signaling networks," Genes \& Development, vol. 11, no. 18, pp. 2295-2322, 1997.

[61] F. Blasi, C. Page, G. M. Rossolini et al., "The effect of $\mathrm{N}$-acetylcysteine on biofilms: implications for the treatment of respiratory tract infections," Respiratory Medicine, vol. 117, pp. 190-197, 2016.

[62] A. C. Olofsson, M. Hermansson, and H. Elwing, "N-AcetylL-cysteine affects growth, extracellular polysaccharide production, and bacterial biofilm formation on solid surfaces," Applied and Environmental Microbiology, vol. 69, no. 8, pp. 4814-4822, 2003.

[63] M. Yamada, K. Ishihara, T. Ogawa, and K. Sakurai, “The inhibition of infection by wound pathogens on scaffold in tissueforming process using $\mathrm{N}$-acetyl cysteine," Biomaterials, vol. 32, no. 33, pp. 8474-8485, 2011. 
[64] M. AlMatar, T. Batool, and E. A. Makky, "Therapeutic potential of N-acetylcysteine for wound healing, acute bronchiolitis, and congenital heart defects," Current Drug Metabolism, vol. 17, no. 2, pp. 156-167, 2016.

[65] M. Deniz, H. Borman, T. Seyhan, and M. Haberal, “An effective antioxidant drug on prevention of the necrosis of zone of stasis: N-acetylcysteine," Burns, vol. 39, no. 2, pp. 320-325, 2013.

[66] B. Yilmaz, G. Turkcu, E. Sengul, A. Gul, F. E. Ozkurt, and M. Akdag, "Efficacy of $\mathrm{N}$-acetylcysteine on wound healing of nasal mucosa," The Journal of Craniofacial Surgery, vol. 26, no. 5, pp. e422-e426, 2015.

[67] A. Oguz, O. Uslukaya, U. Alabalik, A. Turkoglu, M. Kapan, and Z. Bozdag, "Topical N-acetylcysteine improves wound healing comparable to dexpanthenol: an experimental study," International Surgery, vol. 100, no. 4, pp. 656-661, 2015.

[68] C. Fischak, R. Klaus, R. M. Werkmeister et al., "Effect of topically administered chitosan-N-acetylcysteine on corneal wound healing in a rabbit model," Journal of Ophthalmology, vol. 2017, Article ID 5192924, 6 pages, 2017.

[69] S. De Flora, C. Bennicelli, P. Zanacchi, A. Camoirano, A. Morelli, and A. De Flora, "In vitro effects of Nacetylcysteine on the mutagenicity of direct-acting compounds and procarcinogens," Carcinogenesis, vol. 5, no. 4, pp. 505-510, 1984.

[70] S. De Flora, A. Izzotti, F. D'Agostini, and R. M. Balansky, "Mechanisms of $\mathrm{N}$-acetylcysteine in the prevention of DNA damage and cancer, with special reference to smokingrelated end-points," Carcinogenesis, vol. 22, no. 7, pp. 9991013, 2001.

[71] R. L. Siegel, K. D. Miller, and A. Jemal, "Cancer statistics, 2015,” CA: a Cancer Journal for Clinicians, vol. 65, no. 1, pp. 5-29, 2015.

[72] H. Schliephake, "Prognostic relevance of molecular markers of oral cancer-a review," International Journal of Oral and Maxillofacial Surgery, vol. 32, no. 3, pp. 233-245, 2003.

[73] N. van Zandwijk, O. Dalesio, U. Pastorino, N. de Vries, and H. van Tinteren, "EUROSCAN, a randomized trial of vitamin $\mathrm{A}$ and $\mathrm{N}$-acetylcysteine in patients with head and neck cancer or lung cancer. For the EUropean Organization for Research and Treatment of Cancer Head and Neck and Lung Cancer Cooperative Groups," Journal of the National Cancer Institute, vol. 92, no. 12, pp. 977-986, 2000.

[74] S. De Flora, G. Ganchev, M. Iltcheva et al., "Pharmacological modulation of lung carcinogenesis in smokers: preclinical and clinical evidence," Trends in Pharmacological Sciences, vol. 37, no. 2, pp. 120-142, 2016.

[75] F. J. Van Schooten, A. Besaratinia, S. De Flora et al., "Effects of oral administration of $\mathrm{N}$-acetyl-L-cysteine: a multibiomarker study in smokers," Cancer Epidemiology and Prevention Biomarkers, vol. 11, no. 2, pp. 167-175, 2002.

[76] S. Temam, H. Kawaguchi, A. K. El-Naggar et al., "Epidermal growth factor receptor copy number alterations correlate with poor clinical outcome in patients with head and neck squamous cancer," Journal of Clinical Oncology, vol. 25, no. 16, pp. 2164-2170, 2007.

[77] H. Kamata, Y. Shibukawa, S. I. Oka, and H. Hirata, "Epidermal growth factor receptor is modulated by redox through multiple mechanisms. Effects of reductants and $\mathrm{H} 2 \mathrm{O} 2$," European Journal of Biochemistry, vol. 267, no. 7, pp. 19331944, 2000.
[78] M. F. Lee, C. Y. Chan, H. C. Hung, I. T. Chou, A. S. Yee, and C. Y. Huang, "N-Acetylcysteine (NAC) inhibits cell growth by mediating the EGFR/Akt/HMG box-containing protein 1 (HBP1) signaling pathway in invasive oral cancer," Oral Oncology, vol. 49, no. 2, pp. 129-135, 2013.

[79] J. Luo, T. Tsuji, H. Yasuda, Y. Sun, Y. Fujigaki, and A. Hishida, "The molecular mechanisms of the attenuation of cisplatin-induced acute renal failure by $\mathrm{N}$-acetylcysteine in rats," Nephrology, Dialysis, Transplantation, vol. 23, no. 7, pp. 2198-2205, 2008.

[80] J. Yoo, S. J. Hamilton, D. Angel et al., "Cisplatin otoprotection using transtympanic L-N-acetylcysteine: a pilot randomized study in head and neck cancer patients," The Laryngoscope, vol. 124, no. 3, pp. E87-E94, 2014.

[81] L. Pendyala and P. J. Creaven, "Pharmacokinetic and pharmacodynamic studies of $\mathrm{N}$-acetylcysteine, a potential chemopreventive agent during a phase I trial," Cancer Epidemiology, Biomarkers \& Prevention, vol. 4, no. 3, pp. 245-251, 1995.

[82] S. C. De Rosa, M. D. Zaretsky, J. G. Dubs et al., "N-Acetylcysteine replenishes glutathione in HIV infection," European Journal of Clinical Investigation, vol. 30, no. 10, pp. 915929, 2000.

[83] A. Witschi, S. Reddy, B. Stofer, and B. H. Lauterburg, "The systemic availability of oral glutathione," European Journal of Clinical Pharmacology, vol. 43, no. 6, pp. 667-669, 1992.

[84] L. Bonanomi and A. Gazzaniga, "Toxicological, pharmacokinetic and metabolic studies on acetylcysteine," European Journal of Respiratory Diseases Supplement, vol. 111, pp. 45-51, 1980.

[85] L. Borgstrom, B. Kagedal, and O. Paulsen, "Pharmacokinetics of N-acetylcysteine in man," European Journal of Clinical Pharmacology, vol. 31, no. 2, pp. 217-222, 1986.

[86] M. E. Ullian, A. K. Gelasco, W. R. Fitzgibbon, C. N. Beck, and T. A. Morinelli, "N-Acetylcysteine decreases angiotensin II receptor binding in vascular smooth muscle cells," Journal of the American Society of Nephrology, vol. 16, no. 8, pp. 2346-2353, 2005.

[87] M. Hayakawa, H. Miyashita, I. Sakamoto et al., "Evidence that reactive oxygen species do not mediate NF- $\kappa \mathrm{B}$ activation," The EMBO Journal, vol. 22, no. 13, pp. 3356-3366, 2003.

[88] B. Sarnstrand, A. H. Jansson, G. Matuseviciene, A. Scheynius, S. Pierrou, and H. Bergstrand, "N,N'-Diacetyl-L-cystine-the disulfide dimer of $\mathrm{N}$-acetylcysteine-is a potent modulator of contact sensitivity/delayed type hypersensitivity reactions in rodents," The Journal of Pharmacology and Experimental Therapeutics, vol. 288, no. 3, pp. 1174-1184, 1999.

[89] E. M. Grandjean, P. H. Berthet, R. Ruffmann, and P. H. Leuenberger, "Cost-effectiveness analysis of oral $\mathrm{N}$-acetylcysteine as a preventive treatment in chronic bronchitis," Pharmacological Research, vol. 42, no. 1, pp. 39-50, 2000.

[90] S. N. Chen and M. Z. Hoffman, "Effect of $\mathrm{pH}$ on the reactivity of the carbonate radical in aqueous solution," Radiation Research, vol. 62, no. 1, pp. 18-27, 1975.

[91] K. M. Miranda, N. Paolocci, T. Katori et al., "A biochemical rationale for the discrete behavior of nitroxyl and nitric oxide in the cardiovascular system," Proceedings of the National Academy of Sciences of the United States of America, vol. 100, no. 16, pp. 9196-9201, 2011.

[92] A. V. Peskin and C. C. Winterbourn, "Kinetics of the reactions of hypochlorous acid and amino acid chloramines with 
thiols, methionine, and ascorbate," Free Radical Biology \& Medicine, vol. 30, no. 5, pp. 572-579, 2001.

[93] O. Skaff, D. I. Pattison, and M. J. Davies, "Hypothiocyanous acid reactivity with low-molecular-mass and protein thiols: absolute rate constants and assessment of biological relevance," The Biochemical Journal, vol. 422, no. 1, pp. 111117, 2009.

[94] C. C. Winterbourn and D. Metodiewa, "Reactivity of biologically important thiol compounds with superoxide and hydrogen peroxide," Free Radical Biology \& Medicine, vol. 27, no. 3-4, pp. 322-328, 1999.

[95] O. I. Aruoma, B. Halliwell, B. M. Hoey, and J. Butler, "The antioxidant action of $\mathrm{N}$-acetylcysteine: its reaction with hydrogen peroxide, hydroxyl radical, superoxide, and hypochlorous acid," Free Radical Biology \& Medicine, vol. 6, no. 6, pp. 593-597, 1989.

[96] W. A. Prutz, H. Monig, J. Butler, and E. J. Land, "Reactions of nitrogen dioxide in aqueous model systems: oxidation of tyrosine units in peptides and proteins," Archives of Biochemistry and Biophysics, vol. 243, no. 1, pp. 125-134, 1985.

[97] M. Benrahmoune, P. Therond, and Z. Abedinzadeh, "The reaction of superoxide radical with $\mathrm{N}$-acetylcysteine," Free Radical Biology \& Medicine, vol. 29, no. 8, pp. 775-782, 2000.

[98] M. Trujillo and R. Radi, "Peroxynitrite reaction with the reduced and the oxidized forms of lipoic acid: new insights into the reaction of peroxynitrite with thiols," Archives of Biochemistry and Biophysics, vol. 397, no. 1, pp. 91-98, 2002.

[99] E. C. Kim, M. K. Kim, R. Leesungbok, S. W. Lee, and S. J. Ahn, "Co-Cr dental alloys induces cytotoxicity and inflammatory responses via activation of Nrf2/antioxidant signaling pathways in human gingival fibroblasts and osteoblasts," Dental Materials, vol. 32, no. 11, pp. 1394-1405, 2016.

[100] S. Ma, L. Shan, Y. H. Xiao et al., "The cytotoxicity of methacryloxylethyl cetyl ammonium chloride, a cationic antibacterial monomer, is related to oxidative stress and the intrinsic mitochondrial apoptotic pathway," Brazilian Journal of Medical and Biological Research, vol. 44, no. 11, pp. 1125-1133, 2011.

[101] N. R. Kim, H. C. Park, I. Kim, B. S. Lim, and H. C. Yang, "In vitro cytocompatibility of $\mathrm{N}$-acetylcysteine-supplemented dentin bonding agents," Journal of Endodontics, vol. 36, no. 11, pp. 1844-1850, 2010.

[102] H. Minamikawa, M. Yamada, Y. Deyama et al., "Effect of $\mathrm{N}$-acetylcysteine on rat dental pulp cells cultured on mineral trioxide aggregate," Journal of Endodontics, vol. 37, no. 5, pp. 637-641, 2011.

[103] D. H. Lee, B. S. Lim, Y. K. Lee, and H. C. Yang, "Mechanisms of root canal sealers cytotoxicity on osteoblastic cell line MC3T3-E1," Oral Surgery, Oral Medicine, Oral Pathology, Oral Radiology, and Endodontics, vol. 104, no. 5, pp. 717721, 2007.

[104] M. C. Chang, L. D. Lin, M. T. Wu et al., "Effects of camphorquinone on cytotoxicity, cell cycle regulation and prostaglandin E2 production of dental pulp cells: role of ROS, ATM/ Chk2, MEK/ERK and hemeoxygenase-1," PLoS One, vol. 10, no. 12, article e0143663, 2015.

[105] K. Pawlowska-Goral, E. Kurzeja, and M. Stec, "N-Acetylcysteine protects against fluoride-induced oxidative damage in primary rat hepatocytes," Toxicology In Vitro, vol. 27, no. 8, pp. 2279-2282, 2013.
[106] A. Mohsen, A. Gomaa, F. Mohamed et al., "Antibacterial, antibiofilm activity of some non-steroidal anti-inflammatory drugs and $\mathrm{N}$-acetyl cysteine against some biofilm producing uropathogens," American Journal of Epidemiology and Infectious Disease, vol. 3, no. 1, pp. 1-9, 2015.

[107] L. Drago, E. De Vecchi, R. Mattina, and C. L. Romano, "Activity of N-acetyl-L-cysteine against biofilm of Staphylococcus aureus and Pseudomonas aeruginosa on orthopedic prosthetic materials," The International Journal of Artificial Organs, vol. 36, no. 1, pp. 39-46, 2018.

[108] S. Aslam and R. O. Darouiche, "Role of antibiofilmantimicrobial agents in controlling device-related infections," The International Journal of Artificial Organs, vol. 34, no. 9, pp. 752-758, 2011.

[109] M. A. El-Feky, M. S. El-Rehewy, M. A. Hassan, H. A. Abolella, R. M. Abd El-Baky, and G. F. Gad, "Effect of ciprofloxacin and $\mathrm{N}$-acetylcysteine on bacterial adherence and biofilm formation on ureteral stent surfaces," Polish Journal of Microbiology, vol. 58, no. 3, pp. 261-267, 2009.

[110] S. Aslam, B. W. Trautner, V. Ramanathan, and R. O. Darouiche, "Combination of tigecycline and N-acetylcysteine reduces biofilm-embedded bacteria on vascular catheters," Antimicrobial Agents and Chemotherapy, vol. 51, no. 4, pp. 1556-1558, 2007.

[111] B. Leite, F. Gomes, P. Teixeira, C. Souza, E. Pizzolitto, and R. Oliveira, "Combined effect of linezolid and Nacetylcysteine against Staphylococcus epidermidis biofilms," Enfermedades Infecciosas y Microbiología Clínica, vol. 31, no. 10, pp. 655-659, 2013.

[112] S. Kirmusaoğlu, S. Yurdugül, and M. Esra Koçoğlu, "The effect of $\mathrm{N}$-acetylcysteine on growth and biofilm formation in Staphylococcus epidermidis strains," Turkish Journal of Medical Sciences, vol. 42, no. 4, pp. 689-694, 2012.

[113] F. Gomes, B. Leite, P. Teixeira, J. Azeredo, and R. Oliveira, "Farnesol in combination with $\mathrm{N}$-acetylcysteine against Staphylococcus epidermidis planktonic and biofilm cells," Brazilian Journal of Microbiology, vol. 43, no. 1, pp. 235242, 2012.

[114] M. Venkatesh, L. Rong, I. Raad, and J. Versalovic, "Novel synergistic antibiofilm combinations for salvage of infected catheters," Journal of Medical Microbiology, vol. 58, no. 7, pp. 936-944, 2009.

[115] A. Marchese, M. Bozzolasco, L. Gualco, E. A. Debbia, G. C. Schito, and A. M. Schito, "Effect of fosfomycin alone and in combination with $\mathrm{N}$-acetylcysteine on E. coli biofilms," International Journal of Antimicrobial Agents, vol. 22, pp. 95-100, 2003.

[116] J. Lea, A. Conlin, I. Sekirov et al., "In vitro efficacy of $\mathrm{N}$-acetylcysteine on bacteria associated with chronic suppurative otitis media," Journal of Otolaryngology - Head \& Neck Surgery, vol. 43, no. 1, p. 20, 2014.

[117] T. Zhao and Y. Liu, "N-acetylcysteine inhibit biofilms produced by Pseudomonas aeruginosa," BMC Microbiology, vol. 10, no. 1, p. 140, 2010.

[118] R. M. A. el-Baky, D. M. M. A. el Ela, and G. F. M. Gad, "N-acetylcysteine inhibits and eradicates candida albicans biofilms," American Journal of Infectious Diseases and Microbiology, vol. 2, no. 5, pp. 122-130, 2014. 


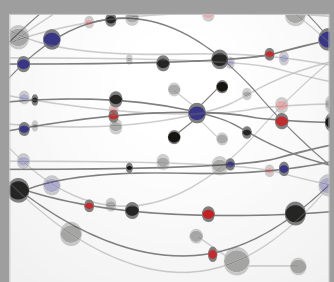

The Scientific World Journal
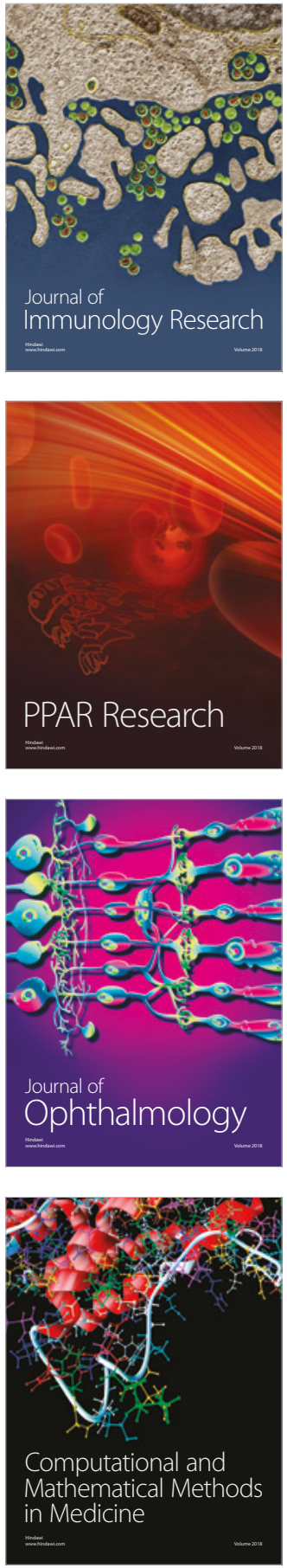

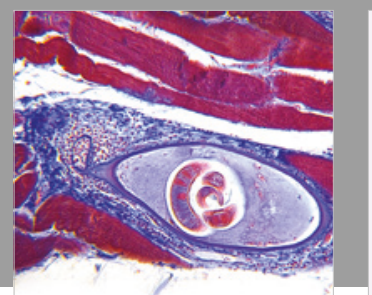

Gastroenterology Research and Practice

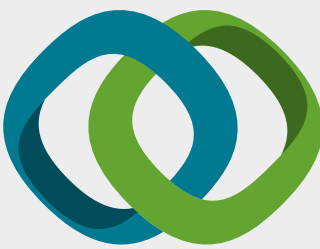

\section{Hindawi}

Submit your manuscripts at

www.hindawi.com
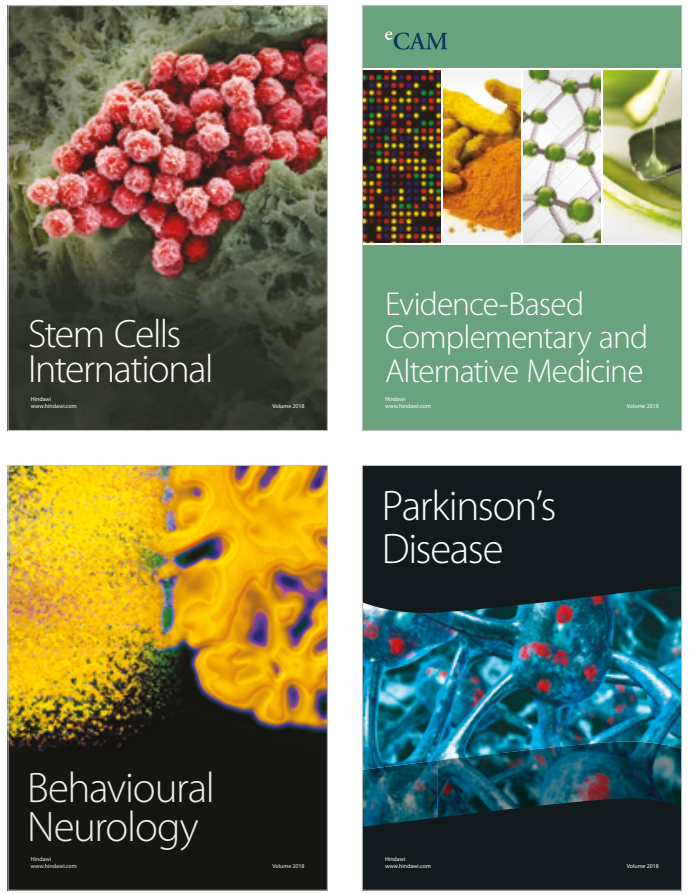

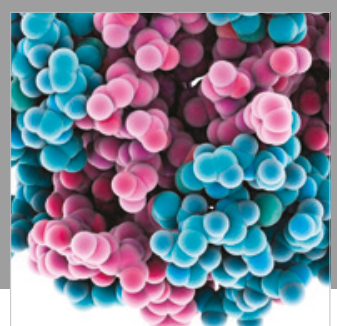

ournal of

Diabetes Research

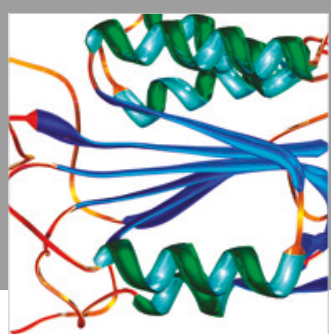

Disease Markers
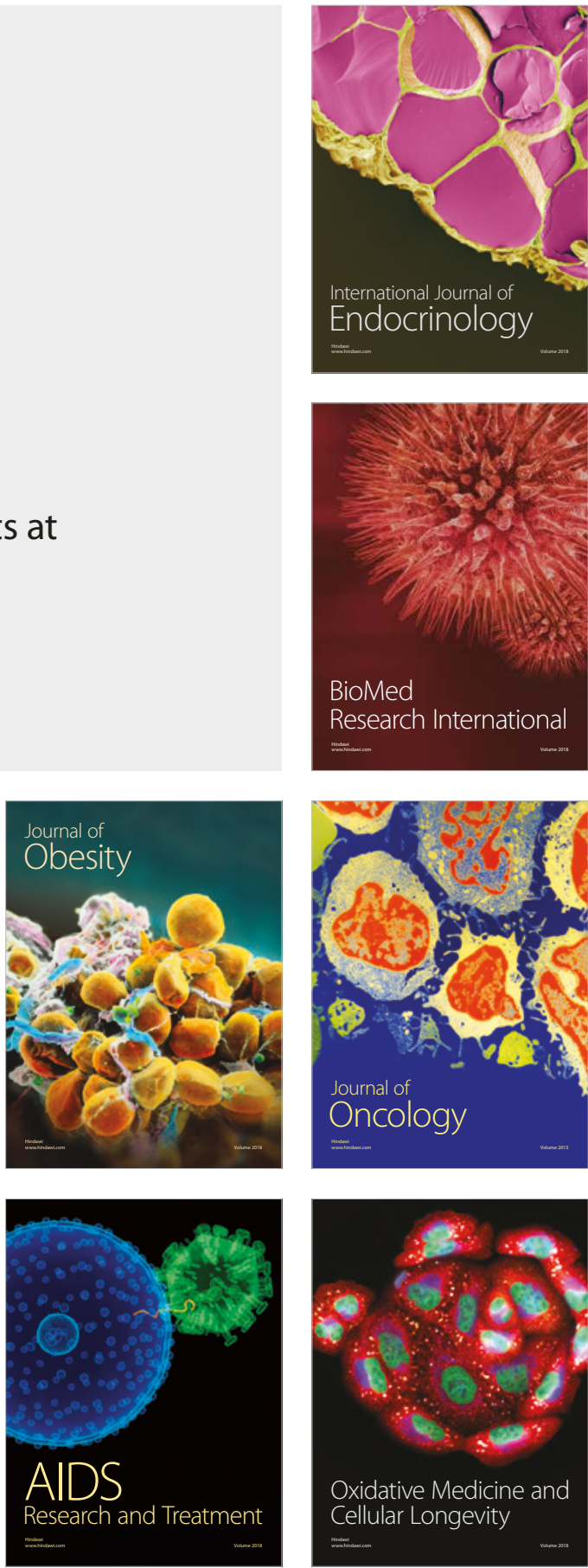